\title{
Intra-thallus variation of phenolic compounds, antioxidant activity, and phenolsulphatase activity in Cystoseira tamariscifolia (Phaeophyceae) from southern Spain
}

\section{Variación intratalo de compuestos fenólicos, actividad antioxidante y actividad de la fenolsulfatasa en Cystoseira tamariscifolia (Phaeophyceae) del sur de España}

\author{
Roberto Teófilo Abdala-Díaz ${ }^{1}$, Alejandro Cabello-Pasini², Eugenia Márquez-Garridoº, \\ Félix López Figueroa ${ }^{1}$ \\ ${ }^{1}$ Departmento de Ecología, Facultad de Ciencias, Universidad de Málaga, Campus Universitario de Teatinos s/n, \\ Málaga E-29071, Spain. \\ 2 Instituto de Investigaciones Oceanológicas, Universidad Autónoma de Baja California, Carretera \\ Transpeninsular Ensenada-Tijuana No. 3917, Fraccionamiento Playitas, Ensenada 22860, Baja California, \\ México. \\ * Corresponding author. E-mail: abdala@uma.es
}

\begin{abstract}
Intra-thallus variation in phenolic content, antioxidant activity, and phenolsulphatase activity (EC 3.1.6.1) was studied in Cystoseira tamariscifolia (Phaeophyceae) from southern Spain. Significant differences in the content of phenolic compounds were found among apical, middle, and basal sections of the thallus of $C$. tamariscifolia. The concentrations of phenolic compounds and of phenolsulphatase activity were highest in the apical section and decreased toward the basal section. There was a highly significant correlation between the concentration of phenolic compounds and antioxidant and phenolsulphatase activities in C. tamariscifolia. Phenol excretion and phenolsulfatase activity were significantly correlated with integrated irradiance. Cystoseira tamariscifolia grows in tightly packed turfs that promote auto-shading in the middle and basal sections of its thalli, and it is thus likely that the higher polyphenol content in the apical section of this species is a response to the higher exposure to ultraviolet radiation and photosynthetically active radiation relative to the middle and basal sections. These results suggest that this excretion of phenolic compounds might function as a protective mechanism serving as a radiation filter in the immediate surroundings of the C. tamariscifolia thalli.
\end{abstract}

Key words: antioxidant activity, Cystoseira tamariscifolia, phenolic compounds, phenolsulphatase activity.

RESUMEN. Se estudió la variación intratalo del contenido fenólico, la actividad antioxidante y la actividad de la fenolsulfatasa (EC 3.1.6.1) en Cystoseira tamariscifolia (Phaeophyceae) del sur de España. Se encontraron diferencias significativas en el contenido de los compuestos fenólicos entre las secciones apical, media y basal del talo de $C$. tamariscifolia. La concentración de los compuestos fenólicos y la actividad de la fenolsulfatasa fueron mayores en la sección apical y disminuyeron hacia la sección basal. Se observó una correlación significativa entre la concentración de los compuestos fenólicos y la actividad antioxidante y de la fenolsulfatasa en C. tamariscifolia. Tanto la excreción de fenoles en el agua de mar como la actividad de la fenolsulfatasa se correlacionaron significativamente con la radiación integrada. Esta especie crece en bosques densos que proporcionan autosombra a las secciones media y basal de los talos, y es probable que el mayor contenido de polifenoles en la sección apical se debe a una mayor exposición a radiación fotosintéticamente activa y radiación ultravioleta en comparación con las secciones media y basal. Estos resultados sugieren que la excreción de compuestos fenólicos funciona como un mecanismo de protección que proporciona un filtro de radiación en las inmediaciones de los talos de C. tamariscifolia.

Palabras clave: actividad antioxidante, Cystoseira tamariscifolia, compuestos fenólicos, actividad de la fenolsulfatasa.

\section{INTRODUCTION}

Marine organisms, including seaweeds living in the intertidal zone, are exposed to free radicals and other strong oxidizing agents (Abdala-Díaz et al. 2006, RodríguezTroncoso et al. 2013). Consequently, marine algae synthesize protective enzymes (e.g., superoxide dismutase, peroxidase, glutathione reductase, catalase) and antioxidant compounds

\section{INTRODUCCIÓN}

Los organismos marinos, incluyendo las algas que habitan en la zona intermareal, están expuestos a radicales libres y otros agentes oxidantes (Abdala-Díaz et al. 2006, Rodríguez-Troncoso et al. 2013). Por consiguiente, las algas marinas sintetizan las enzimas protectoras (e.g., superóxido dismutasa, peroxidasa, glutatión reductasa, catalasa) y los 
(e.g., phlorotannins, phospholipids, ascorbic acid, carotenoids, bromophenols, catechins, mycosporine-like amino acids, polysaccharides) as defense mechanisms (Abdala-Díaz et al. 2006, Korbee et al. 2006, Bellassoued et al. 2012). In addition to enzymes, algae and higher plants synthesize structural polyphenols, which also have high antioxidant capabilities (Goodwin and Mercer 1988). Among seaweeds, Phaeophyceae species contain the highest levels of phenolic compounds, mainly as phlorotannins, i.e., phloroglucinol (1,3,5-trihydroxybenzene). Specifically, the highest levels of phlorotannins have been found in species of the orders Fucales and Dictyotales (20-30\% dry weight (DW), Targett et al. 1995).

Phlorotannins, packaged within membrane-bound physodes, appear to play multiple roles in brown algae, both at the cellular and at the organism level (Schoenwaelder 2002). These polyphenols, for example, play an essential role in the protection of brown algae against grazing (Pavia and Toth 2000) and in the anchoring process of the thallus to the substrate (Vreeland et al. 1998). The concentrations of these compounds within the thallus show seasonal, geographical, and daily variations, and are impacted by photosynthetically active radiation (PAR) levels, UV radiation, nutrient concentration, and salinity (Pedersen 1984, Ragan and Glombitza 1986, Yates and Peckol 1993, Pavia et al. 1997, Abdala-Díaz et al. 2006). The diversity of phenolic compounds and the variety of the parameters conditioning their accumulation in brown algae may explain why phenol contents and seaweed zonation are not totally interdependent (Connan et al. 2004).

The synthesis and excretion of polyphenolic compounds have been reported in seaweeds as a defense mechanism against herbivorism and against high UV radiation and PAR levels. The concentration of phlorotannins in the kelp Lessonia nigrescens, for example, increases as a result of increasing UV radiation levels (Gómez and Huovinen 2010). The green alga Dasycladus vermicularis has shown a fourfold increase in the excretion of coumarins with increasing PAR levels (Pérez-Rodríguez et al. 2001). The increase in polyphenolic compounds in the surrounding water reduces light transmission and ultimately protects the seaweed against high levels of PAR and UV radiation.

Phenolsulphatase (arylsulphatase) (E.C. 3.1.6.1) is a widely distributed enzyme in bacteria, algae, fungi, higher plants, and animals. This enzyme is partially responsible for the hydrolisis of sulphate esters in crude plant extracts (Farooqui et al. 1977). The hydrolysis of sulphated esters ( $p$-nitrocatechol sulphate, $p$-nitrophenyl sulphate, 6-benzoyl2-naphthyl sulphate, etc.) by phenolsulphatase has also been detected in the thallus of the marine alga Cystoseira tamariscifolia (Knöss and Glombitza 1993). It is unknown, however, if this enzyme plays an important role in the hydrolysis and excretion of polyphenols under stressful conditions.

Cystoseira tamariscifolia is abundant in the intertidal zone of the Mediterranean coast of Spain. Seaweeds living in the intertidal zone, including $C$. tamariscifolia, are exposed compuestos antioxidantes (e.g., florotaninos, fosfolípidos, ácido ascórbico, carotenoides, bromofenoles, catequinas, aminoácidos tipo micosporina, polisacáridos) como mecanismo de defensa (Abdala-Díaz et al. 2006, Korbee et al. 2006, Bellassoued et al. 2012). Además de las enzimas, las algas y plantas superiores sintetizan los polifenoles estructurales que también poseen una alta capacidad antioxidante (Goodwin y Mercer 1988). Entre las algas marinas, las pertenecientes a la clase Phaeophyceae contienen los niveles más altos de compuestos fenólicos, principalmente en forma de florotaninos, i.e., floroglucinol (1,3,5-trihidroxibenceno). Los mayores niveles de florotaninos han sido encontrados en las algas del orden Fucales y orden Dictyotales (20-30\% de peso seco (PS), Targett et al. 1995).

Los florotaninos, empaquetados en vesículas llamadas fisoides unidas a la membrana, parecen desempeñar múltiples funciones en las algas pardas, tanto a nivel celular como del organismo (Schoenwaelder 2002). Por ejemplo, estos polifenoles juegan un papel fundamental en la protección de las algas pardas contra el pastoreo (Pavia y Toth 2000) y en el proceso de anclaje de la planta al sustrato (Vreeland et al. 1998). Las concentraciones de estos compuestos muestran variaciones estacionales, geográficas y diarias, y son afectadas por los niveles de radiación fotosintéticamente activa (PAR, por sus siglas en inglés) y radiación UV, la concentración de nutrientes y la salinidad (Pedersen 1984, Ragan y Glombitza 1986, Yates y Peckol 1993, Pavia et al. 1997, Abdala-Díaz et al. 2006). La diversidad de los compuestos fenólicos y la variedad de los parámetros que condicionan su acumulación en las algas pardas pueden explicar por qué los contenidos fenólicos y la zonificación de algas no son totalmente interdependientes (Connan et al. 2004).

Se ha documentado que el proceso de síntesis y excreción de compuestos polifenólicos en algas marinas es un mecanismo de defensa contra el herbivorismo y niveles altos de radiación UV y PAR. La concentración de florotaninos en el alga Lessonia nigrescens, por ejemplo, aumenta según incrementa el nivel de radiación UV (Gómez y Huovinen 2010). La excreción de coumarinas en el alga verde Dasycladus vermicularis aumentó cuatro veces a mayores niveles de PAR (Pérez-Rodríguez et al. 2001). Un incremento de los compuestos polifenólicos en el agua circundante reduce la transmisión de luz y protege a las algas contra niveles altos de radiación UV y PAR.

La fenolsulfatasa (arilsulfatasa) (E.C. 3.1.6.1) es una enzima ampliamente distribuida en bacterias, algas, hongos, plantas superiores y animales. Esta enzima es parcialmente responsable de la hidrólisis de ésteres de sulfato en los extractos crudos de plantas (Farooqui et al. 1977). En el talo del alga marina Cystoseira tamariscifolia se ha detectado la hidrólisis de ésteres sulfatados (sulfato de $p$-nitrocatecol, sulfato de $p$-nitrofenil, sulfato de 6-benzol-2-naftil, etc.) por la fenolsulfatasa (Knöss y Glombitza 1993); sin embargo, se desconoce si esta enzima juega un papel importante en la hidrólisis y excreción de polifenoles en condiciones de estrés. 
to a wide range of UV radiation dosages and PAR. While immersed, these seaweeds might be light-limited; however, at emersion, the apical portions of some seaweeds might be exposed to strong desiccation and to high doses of PAR and UV radiation. In addition to dynamic photoinhibition, C. tamariscifolia has developed efficient mechanisms of photoprotection against these environmentally stressful conditions (Hader and Figueroa 1997). Studies have revealed, for example, that the excretion of phenolic compounds increases under high irradiance conditions (Pérez-Rodríguez et al. 2001, Koivikko et al. 2005, Abdala-Díaz et al. 2006, Gómez and Huovinen 2010). It is thus possible that phenolsulphatase activity forms the active natural substances at rates correlated with those of their excretion. The objective of this study was to relate the intra-thallus distribution of phenolic compounds and antioxidant and phenolsulphatase activities as a balance between production and excretion of phenols in C. tamariscifolia (Phaeophyceae) from southern Spain.

\section{MATERIALS AND METHODS}

\section{Seaweed material}

Cystoseira tamariscifolia was collected early in the morning in July 2010 at Cabo de Gata-Níjar Natural Park (36 $52^{\prime}$ N, 2 ${ }^{\circ} 12^{\prime} \mathrm{W}$; Almería, Spain.) in the Mediterranean. Seaweeds were detached from the rocky substrate (intertidal zone) and transported in liquid nitrogen to the laboratory for analysis.

\section{Phenol extraction and assay}

Seaweed thalli were divided into basal, middle, and apical sections. Samples from each section $(n=5)$ were homogenized in liquid nitrogen using a mortar and pestle, and extracted overnight with $2.5 \mathrm{~mL}$ of $80 \%$ (v/v) methanol. The homogenate was centrifuged at $19,000 \mathrm{~g}$ for $15 \mathrm{~min}$ and the supernatant was collected. Total phenolic compounds were determined using phloroglucinol (1,3,5-trihydroxybenzene, Sigma P-3502) as a standard (Folin and Ciocalteu 1927).

\section{Phenolsulphatase activity}

Phenolsulphatase activity in the thallus of C. tamariscifolia was determined colorimetrically by incubating approximately $50 \mathrm{mg}$ (wet weight) of tissue in $2.1 \mathrm{~mL}$ of assay buffer (225 $\mu \mathrm{L}$ 0.4 M MES-Tris, pH 6.2, $225 \mu \mathrm{L} 2.22$ mM p-nitrocatechol sulphate, $600 \mu \mathrm{L} \mathrm{H}_{2} \mathrm{O}$ ) and $\mathrm{H}_{2} \mathrm{O}(1: 1)$ in darkness for $24 \mathrm{~h}$ at room temperature according to Knöss and Glombitza (1993). The reaction was stopped by adding three drops of $5 \mathrm{M} \mathrm{NaOH}$. Absorbance of the solution was evaluated at $510 \mathrm{~nm}$, and the concentration of $p$-nitrocatechol was estimated against a standard curve. The phenolsulphatase activity ( $\mu \mathrm{mol}$ nitrocatechol $\mathrm{g}^{-1} \mathrm{DW} \mathrm{h}^{-1}$ ) in each tissue section of $C$. tamariscifolia was calculated.
Cystoseira tamariscifolia es abundante en la zona intermareal de la costa mediterránea de España. Las algas que habitan en la zona intermareal, incluyendo C. tamariscifolia, están expuestas a diferentes niveles de radiación UV y PAR. Mientras están inmersas, estas plantas reciben poca luz, pero cuando emergen, sus porciones apicales pueden quedar expuestas a desecación y a dosis altas de radiación UV y PAR. Aparte de la fotoinhibición dinámica, C. tamariscifolia ha desarrollado mecanismos eficientes de fotoprotección contra estas condiciones ambientalmente estresantes (Hader y Figueroa 1997). Varios trabajos han mostrado, por ejemplo, que la excreción de compuestos fenólicos incrementa en condiciones de alta radiación (Pérez-Rodríguez et al. 2001, Koivikko et al. 2005, Abdala-Díaz et al. 2006, Gómez y Huovinen 2010). Por tanto, es posible que la actividad de la fenolsulfatasa forme las sustancias naturales activas a tasas correlacionadas con los de su excreción. El objetivo de este trabajo fue relacionar la distribución intratalo de los compuestos fenólicos y la actividad antioxidante y actividad de la fenolsulfatasa como un balance entre la producción y excreción de fenoles en C. tamariscifolia (Phaeophyceae) del sur de España.

\section{MATERIALES Y MÉTODOS}

\section{Material algal}

En julio de 2010 se recolectaron muestras de $C$. tamariscifolia temprano en la mañana en el Parque Natural Cabo de Gata-Níjar (36 52' N, 2¹2' W; Almería, España) en el Mediterráneo. Las algas fueron desprendidas del sustrato rocoso (zona intermareal) y transportadas en nitrógeno líquido al laboratorio para su análisis.

\section{Extracción y ensayo de fenoles}

Los talos fueron divididos en tres secciones: basal, media y apical. Se homogeneizaron muestras de cada sección $(n=5)$ en nitrógeno líquido con un mortero y se extrajeron con $2.5 \mathrm{~mL}$ de metanol al $80 \%(\mathrm{v} / \mathrm{v})$. Se centrifugó el homogenado a 19,000 $g$ durante 15 min y se recolectó el sobrenadante. Los compuestos fenólicos totales fueron determinados usando floroglucinol (1,3,5-trihidroxibenceno, Sigma P-3502) como un estándar (Folin y Ciocalteu 1927).

\section{Actividad de la fenolsulfatasa}

La actividad de la enzima fenolsulfatasa en el talo de C. tamariscifolia se determinó colorimétricamente. Se incubaron aproximadamente $50 \mathrm{mg}$ (peso húmedo) de tejido en $2.1 \mathrm{~mL}$ de tampón de ensayo $(225 \mu \mathrm{L}$ de MES-Tris $0.4 \mathrm{M}$, pH 6.2, $225 \mu \mathrm{L}$ de sulfato de $p$-nitrocatecol $2.22 \mathrm{mM}, 600 \mu \mathrm{L}$ de $\left.\mathrm{H}_{2} \mathrm{O}\right)$ y $\mathrm{H}_{2} \mathrm{O}$ (1:1) en la oscuridad durante $24 \mathrm{~h}$ a temperatura ambiente según Knöss y Glombitza (1993). La reacción se detuvo añadiendo tres gotas de $\mathrm{NaOH} 5 \mathrm{M}$. Se evaluó la 


\section{Antioxidant activity}

Radical scavenging and antioxidant activities of the extracts were assessed by the 2,2-diphenyl-1-picrylhydrazyl (DPPH) free-radical method (Brand-Williams et al. 1995). Aliquots of $300 \mu \mathrm{L}$ of extracts were added to $3 \mathrm{~mL}$ of DPPH solution $(0.358 \mathrm{mM})$ in $90 \%(\mathrm{v} / \mathrm{v})$ methanol. The samples were incubated for $1 \mathrm{~h}$ and the absorbance was read at $517 \mathrm{~nm}$ against demineralized water as blank. The absorbance was then transformed into a percentage of inhibition versus demineralized water. The concentration required to obtain a $50 \%$ antioxidant effect $\left(\mathrm{EC}_{50}\right)$ was determined by diluting the plant extract solution in methanol and testing for DPPH.

\section{Phenol excretion}

To evaluate the effect of PAR levels on the rate of excretion of phenolic compounds and the phenolsulphatase activity, C. tamariscifolia tissue was incubated under different intensities of yellow light provided by low-pressure sodium lamps (Philips, USA, low SOX $=30 \mu \mathrm{mol} \mathrm{m}{ }^{-2} \mathrm{~s}^{-1}$ and high SOX $\left.=360 \mu \mathrm{mol} \mathrm{m} \mathrm{m}^{-2} \mathrm{~s}^{-1}\right)$. Experiments were performed in acrylic containers $(2 \mathrm{~L}, n=3)$ in a growth chamber at $15^{\circ} \mathrm{C}$, and tissue was maintained in constant suspension by bubbling air into each container. Water samples were taken at 18 , $24,36,48$, and $60 \mathrm{~h}$, and absorbance was determined at $\lambda=$ $266 \mathrm{~nm}$ (maximum absorbance of phloroglucinol, Waterman and Mole 1994). The concentration of phenols excreted in the seawater were determined using the molar extinction coefficient of phloroglucinol in seawater $\left(\varepsilon=0.00169 \mathrm{M} \mathrm{cm}^{-1}\right)$. The molar concentration was determined using the following equation:

$$
C=A_{266} /(\varepsilon \times L)
$$

where $C$ is the concentration of phenols (M), $A_{266}$ is the absorbance at $266 \mathrm{~nm}, \varepsilon$ is the molar extinction coefficient of phloroglucinol in seawater, and $L$ is path length. The concentration of excreted phenolic compounds in the seawater was expressed as $\mathrm{mM}$.

\section{Statistical analyses}

Significant differences between phenolic compound concentrations and antioxidant and phenolsulphatase activities in C. tamariscifolia were analyzed by a one-way analysis of variance (ANOVA) after testing for normality and homoscedasticity of the data (Sokal and Rohlf 1995). Differences in concentrations at specific sections of the thallus were determined using Newman-Keuls post hoc test, and the significance level was fixed at $P<0.05$. The significance of correlation between phenol content and antioxidant activity as well as between phenol content and phenolsulphatase activity absorbancia de la solución a $510 \mathrm{~nm}$ y se estimó la concentración de $p$-nitrocatecol con una curva estándar. Se calculó la actividad de la fenolsulfatasa ( $\mu \mathrm{mol}$ nitrocatecol g ${ }^{-1} \mathrm{PS} \mathrm{h}^{-1}$ ) en cada sección de tejido de C. tamariscifolia.

\section{Actividad antioxidante}

Se evaluaron las actividades antioxidante y antirradical de los extractos mediante el método del radical libre 2,2-difenil1-picrilhidrazil (DPPH) (Brand-Williams et al. 1995). Se adicionaron alíquotas de $300 \mu \mathrm{L}$ de los extractos a una solución de $3 \mathrm{~mL}$ de DPPH (0.358 mM) en metanol al 90\% (v/v). Las muestras se incubaron durante $1 \mathrm{~h}$ y se midió la absorbancia a $517 \mathrm{~nm}$ usando agua desmineralizada como blanco. La absorbancia fue transformada en un porcentaje de inhibición contra agua desmineralizada. Para determinar la concentración requerida para obtener un efecto antioxidante del 50\% $\left(\mathrm{EC}_{50}\right)$, se diluyó la solución del extracto en metanol y se realizó el ensayo DPPH.

\section{Excreción de compuestos fenólicos}

Para evaluar el efecto de los niveles de PAR en la tasa de excreción de compuestos fenólicos y la actividad de la fenolsulfatasa, se incubó el tejido de C. tamariscifolia bajo diferentes intensidades de luz amarilla proporcionada por lámparas de sodio de baja presión (Philips, EUA, SOX bajo = $30 \mu \mathrm{mol} \mathrm{m}{ }^{-2} \mathrm{~s}^{-1}$ y SOX alto $\left.=360 \mu \mathrm{mol} \mathrm{m}^{-2} \mathrm{~s}^{-1}\right)$. Los experimentos se realizaron en contenedores de acrílico $(2 \mathrm{~L}, n=3)$ en una cámara de crecimiento a $15^{\circ} \mathrm{C}$, manteniendo el tejido en suspensión constante mediante la introducción de burbujas de aire. Se tomaron muestras de agua después de 18, 24, 36, 48 y $60 \mathrm{~h}$, y se determinó la aborbancia a $\lambda=266 \mathrm{~nm}$ (absorbancia máxima de floroglucinol, Waterman y Mole 1994). Se evaluó la concentración de fenoles excretados en el agua de mar mediante el coeficiente de extinción molar de floroglucinol en agua de mar $\left(\varepsilon=0.00169 \mathrm{M} \mathrm{cm}^{-1}\right)$. La concentración molar se determinó con la siguiente ecuación:

$$
C=A_{266} / \varepsilon \times L
$$

donde $C$ es la concentración de fenoles (M), $A_{266}$ es la absorbancia a $266 \mathrm{~nm}, \varepsilon$ es el coeficiente de extinción molar de floroglucinol en agua de mar y $L$ es la longitud de paso de la luz de la cubeta de cuarzo. Se expresó la concentración de compuestos fenólicos excretados en el agua de mar en mM.

\section{Análisis estadísticos}

Las diferencias significativas entre la concentración de compuestos fenólicos y la actividad antioxidante y de la fenolsulfatasa en C.tamariscifolia fueron analizadas mediante un análisis de varianza de una vía (ANOVA) después de comprobar la normalidad y homocedasticidad de 
was tested using Pearson's product-moment correlations. Minimum significance level was established at $P<0.05$.

\section{RESULTS}

\section{Phenol content and phenolsulphatase activity}

The concentration of phenolic compounds among the different sections of the thallus of $C$. tamariscifolia showed significant differences $(P<0.05$, fig. 1$)$. The concentration of phenolic compounds was two- to fourfold greater in the apical section than in the middle and basal sections. The activity of phenolsulphatase also showed significant differences among tissue samples of $C$. tamariscifolia $(P<0.05$, fig. 1). The greatest $(P<0.05)$ phenolsulphatase activity was found in the apical section $\left(900 \mu \mathrm{mol}\right.$ nitrocatechol $\mathrm{g}^{-1}$ $\mathrm{DW} \mathrm{h}^{-1}$ ) and the lowest in the basal section.

\section{Antioxidant capacity}

There was a significant difference $(P<0.05)$ in antioxidant capacity among $C$. tamariscifolia thallus sections (fig. 2). The antioxidant capacity was higher in the apical section and decreased fivefold $(P<0.05)$ towards the basal section. A positive and significant $(P<0.05)$ correlation between phenolic levels in the tissue and phenolsulphatase activity was observed (fig. 3), as well as between phenolic levels in the tissue and the antioxidant capacity (fig. 3). Lowest phenolsulphatase activity and antioxidant capacity were observed in tissue with the lowest phenolic levels, whereas highest phenolsulphatase activity and antioxidant capacity were observed in tissue with the highest phenolic levels.

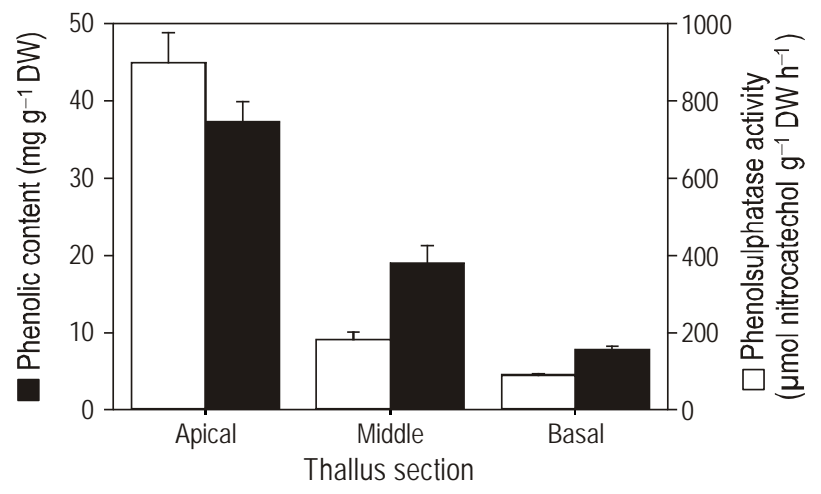

Figure 1. Phenolic compound content and phenolsulphatase activity in the apical, middle, and basal sections of the thallus of Cystoseira tamariscifolia (dry weight, DW). Bars represent mean \pm standard deviation.

Figura 1. Contenido de compuestos fenólicos y actividad de la fenolsulfatasa en las secciones apical, media y basal del talo de Cystoseira tamariscifolia (peso seco, DW). Las barras representan la media \pm desviación estándar. los datos (Sokal y Rohlf 1995). Se determinaron las diferencias de las concentraciones en las secciones específicas de los talos mediante la prueba post hoc de Newman-Keuls, con un nivel de significancia de $P<0.05$. La significancia de la correlación entre el contenido fenólico y la actividad antioxidante y entre el contenido fenólico y la actividad de la fenolsulfatasa se verificó mediante correlaciones productomomento de Pearson. Se estableció un nivel mínimo de significancia de $P<0.05$.

\section{RESULTADOS}

\section{Contenido fenólico y actividad de la fenolsulfatasa}

La concentración de los compuestos fenólicos en las diferentes secciones del talo de $C$. tamariscifolia mostró diferencias significativas $(P<0.05$, fig. 1$)$. La concentración de los compuestos fenólicos fue de dos a cuatro veces mayor en la sección apical que en las secciones media y basal. La actividad de la fenolsulfatasa también mostró diferencias significativas entre las muestras de tejido de $C$. tamariscifolia $(P<0.05$, fig. 1$)$, observándose la mayor actividad $(P<0.05)$ en la sección apical (900 $\mu \mathrm{mol}$ nitrocatecol $\left.\mathrm{g}^{-1} \mathrm{PS} \mathrm{h}^{-1}\right)$ y la menor en la sección basal.

\section{Capacidad antioxidante}

Se observaron diferencias significativas $(P<0.05)$ en la capacidad antioxidante entre las tres secciones del talo de C. tamariscifolia (fig. 2), siendo mayor en la sección apical y cinco veces menor $(P<0.05)$ hacia la sección basal. Se observó una correlación positiva y significativa $(P<0.05)$

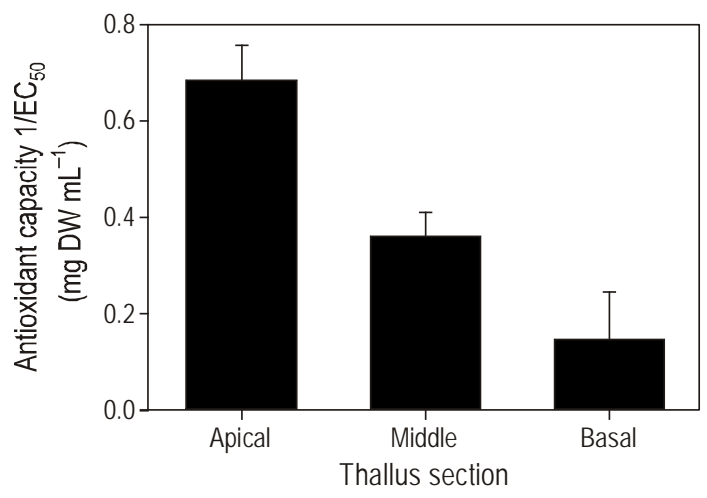

Figure 2. Antioxidant capacity $\left(1 / \mathrm{EC}_{50}\right)$ in the apical, middle, and basal sections of the thallus of Cystoseira tamariscifolia (dry weight, DW). Bars represent mean \pm standard deviation.

Figura 2. Capacidad antioxidante $\left(1 / E_{50}\right)$ en las secciones apical, media y basal del talo de Cystoseira tamariscifolia (peso seco, DW). Las barras representan la media \pm desviación estándar. 


\section{Irradiance and phenol excretion}

There was a positive and significant correlation $(P<$ 0.05 ) between integrated irradiance dosage and phenol excretion, and between integrated irradiance dosage and phenolsulphatase activity (fig. 4). Lowest phenolsulphatase activity and phenolic compound excretion were observed at low integrated dosages, and highest phenolsulphatase activity and phenolic compound excretion were observed at high integrated dosages. In addition, there was an increase in phenolic compound excretion as a function of time when tissue was exposed to low or high SOX light (fig. 5). The excretion rate of phenolic compounds, however, was twofold greater $(P<0.05)$ in tissue incubated under high SOX light than under low SOX light. Excretion rates remained constant during the 60-h incubation period.

\section{Discussion}

Intertidal seaweeds have developed mechanisms to reduce stress caused by changing light regimens and seasonal fluctuations in temperature. These defense mechanisms include antioxidant production, free-radical scavenging phenolic compounds, and/or antioxidant enzymes (JiménezEscring et al. 2001, Lohrmann et al. 2004, Zubia et al. 2009). In Chondrus crispus and Mastocarpus stellatus, for example, the activity of the antioxidant enzymes superoxide dismutase, ascorbate peroxidase, and glutathione reductase is greater in winter than in summer (Lohrmann et al. 2004). This suggests that seaweeds respond to the increase in reactive oxygen species during winter by increasing antioxidant enzymes and phenolic compounds. Cystoseira tamariscifolia from southern Spain is also exposed to wide fluctuations in irradiance, UV radiation, and temperature throughout the year

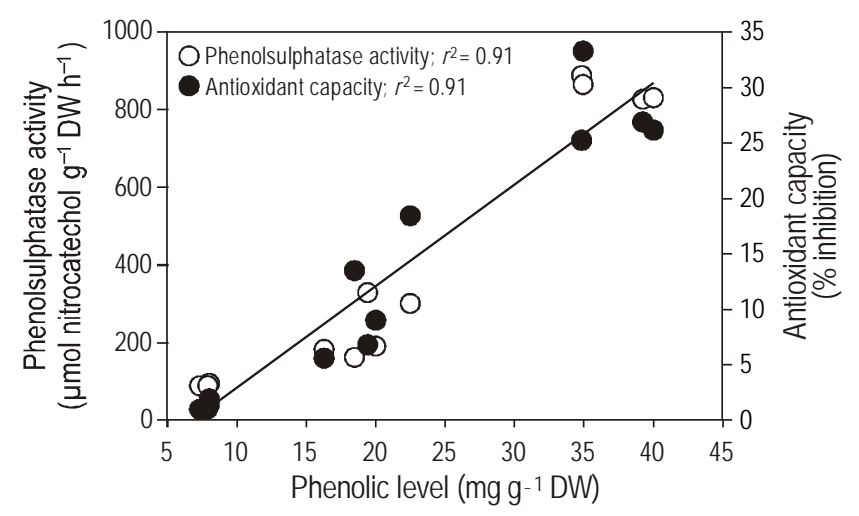

Figure 3. Phenolic compound levels vs phenolsulphatase activity, and phenolic compound levels vs antioxidant capacity in the thallus of Cystoseira tamariscifolia (dry weight, DW).

Figura 3. Nivel de compuestos fenólicos vs actividad de la fenolsulfatasa y nivel de compuestos fenólicos vs capacidad antioxidante en el talo de Cystoseira tamariscifolia (peso seco, DW). entre los niveles de compuestos fenólicos en el tejido y la actividad de la fenolsulfatasa, así como entre los niveles de compuestos fenólicos en el tejido y la capacidad antioxidante (fig. 3). La actividad de la fenolsulfatasa y la capacidad antioxidante fueron menores en los tejidos con menores niveles de compuestos fenólicos y fueron mayores en los tejidos con mayores niveles de compuestos fenólicos.

\section{Irradiación y excreción de fenoles}

Se observó una correlación positiva y significativa $(P<0.05)$ entre la dosis de radiación integrada y la excreción de fenoles, y entre la dosis de radiación integrada y la actividad de la fenolsulfatasa (fig. 4). La actividad de la fenolsulfatasa y la excreción de compuestos fenólicos fueron menores a dosis integradas bajas y mayores a dosis integradas altas. Además, se observó un incremento de la excreción de compuestos fenólicos en función del tiempo cuando el tejido fue expuesto a luz SOX baja o alta (fig. 5); sin embargo, la tasa de excreción de compuestos fenólicos fue dos veces mayor $(P<0.05)$ en tejidos incubados con luz SOX alta que con luz SOX baja. Las tasas de excreción se mantuvieron constantes durante el periodo de incubación de 60 h.

\section{DISCUSIÓN}

Las algas marinas intermareales han desarrollado mecanismos para reducir el estrés causado por cambios en el régimen de luz y variaciones estacionales de la temperatura. Estos mecanismos de defensa incluyen la producción de antioxidantes, la captación de radicales libres mediante compuestos fenólicos, y/o enzimas antioxidantes (JiménezEscring et al. 2001, Lohrmann et al. 2004, Zubia et al. 2009).

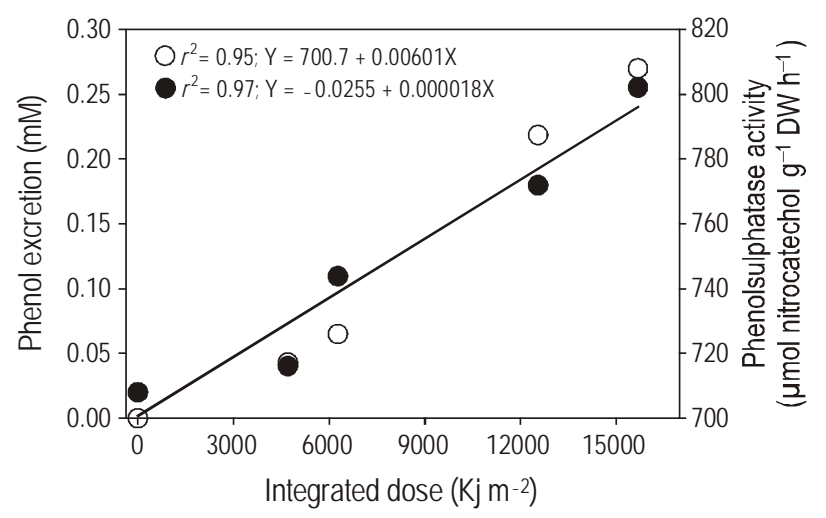

Figure 4. Phenolic compound excretion (open circles) and phenolsulphatase activity (filled circles) in the tissue of Cystoseira tamariscifolia (dry weight, DW) as a function of integrated irradiance dosage.

Figura 4. Excreción de compuestos fenólicos (círculos abiertos) y actividad de la fenolsulfatasa (círculos rellenos) en el tejido de Cystoseira tamariscifolia (peso seco, DW) en función a la dosis de radiación integrada. 


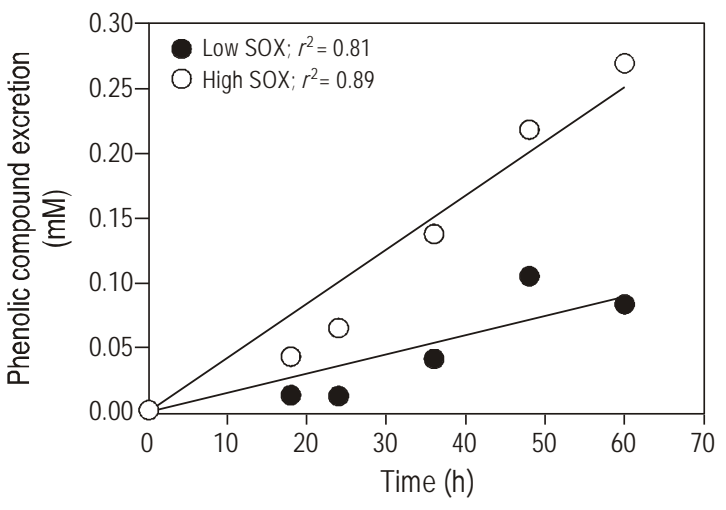

Figure 5. Phenolic compound excretion in Cystoseira tamariscifolia tissue exposed to low and high intensities of yellow light provided by low-pressure sodium lamps (SOX).

Figura 5. Excreción de compuestos fenólicos en el tejido de Cystoseira tamariscifolia expuesto a intensidades altas y bajas de luz amarilla emitida por lámparas de sodio de baja presión (SOX).

(Hader et al. 1997), so it is likely that this species also experiences seasonal fluctuations in antioxidant compounds and enzymes, as has been reported in algae from Brittany, France (Connan et al. 2007).

The phenolic compound content has been shown to vary among species and also within the sections of the thallus of different species. In Ascophyllum nodosum, a greater concentration of phenolic compound has been found in the apical than in the middle and basal sections of the thallus (Geiselman 1980). Intra-thallus variations were also reported in two species of Sargassum and the green alga Dasycladus vermicularis throughout the year, in which the highest levels were observed in the apical section and the lowest concentrations in the basal section and holdfast (Rao and Untawale 1991, Pérez-Rodríguez et al. 2001). In our study, the phenolic content in the thallus of $C$. tamariscifolia was higher in the apical section than in the middle and basal sections. Cystoseira tamariscifolia grows in tightly packed turfs that promote auto-shading in the middle and basal sections of its thalli; thus, it is likely that the higher polyphenol content in the apical section of this species is a response to the higher exposure to PAR and UV radiation relative to the middle and basal sections of the thalli.

Daily variations in phenol contents have also been observed in the brown seaweed Macrocystis integrifolia, with fluctuations related to increasing levels of sunlight and UV radiation (Swanson and Druehl 2002). In C. tamariscifolia, levels of phenolic compounds have been observed to be low early in the morning and to progressively increase towards the end of the day (Abdala-Díaz et al. 2006). This further suggests a relation between the photoregulation of phenol production and the cumulative irradiation during exposure.

The desulphation of polyphenols by phenolsulphatase has been observed in a number of species (Abdala-Díaz 2001). This desulphation of polyphenols has been found to correlate with the excretion of free phenols when seaweeds are
En Chondrus crispus y Mastocarpus stellatus, por ejemplo, la actividad de las enzimas antioxidantes superóxido dismutasa, ascorbato peroxidasa y glutatión reductasa es mayor en invierno que en verano (Lohrmann et al. 2004). Esto sugiere que las algas responden al incremento en la producción de especies reactivas del oxígeno aumentando la producción de enzimas antioxidantes y compuestos fenólicos. Cystoseira tamariscifolia del sur de España también está expuesta a grandes fluctuaciones de luz, radiación UV y temperatura a lo largo del año (Hader et al. 1997), y es probable que también experimenta variaciones estacionales de compuestos y enzimas antioxidantes, como ha sido documentado para algas de Bretaña, Francia (Connan et al. 2007).

Se ha demostrado que el contenido de compuestos fenólicos varía entre especies así como entre las secciones del talo de diferentes especies. En Ascophyllum nodosum se ha observado una mayor concentración de compuestos fenólicos en la sección apical que en las secciones media y basal del talo (Geiselman 1980). También se han documentado variaciones intratalo en dos especies de Sargassum y en el alga verde Dasycladus vermicularis a lo largo del año, observándose los niveles más altos en la sección apical y las concentraciones más bajas en la sección basal y el órgano de fijación (Rao y Untawale 1991, Pérez-Rodríguez et al. 2001). En el presente estudio, el contenido de compuestos fenólicos en el talo de C. tamariscifolia también fue mayor en la sección apical que en las secciones media y basal. Cystoseira tamariscifolia crece en bosques densos que proporcionan autosombra a las secciones media y basal del talo; por lo tanto, es probable que el mayor contenido de polifenoles en la sección apical de esta especie se debe a una mayor exposición a radiación UV y PAR en comparación con las secciones media y basal.

Asimismo, se han registrado variaciones en el contenido de fenoles en el alga parda Macrocystis integrifolia, las cuales se han relacionado con un aumento en los niveles de luz solar y radiación UV (Swanson y Druehl 2002). En C. tamariscifolia, Abdala-Díaz et al. (2006) encontraron que los niveles de compuestos fenólicos son bajos en la mañana y aumentan progresivamente durante el día. Esto sugiere una relación entre la fotoregulación de la producción de fenoles y la radiación acumulativa durante la exposición.

La desulfuración de polifenoles por la fenolsulfatasa ha sido observada en varias especies (Abdala-Díaz 2001). Se ha encontrado que esta desulfuración se correlaciona con la excreción de fenoles libres cuando las algas están expuestas a condiciones de estrés como la radiación solar en verano. Como también se ha mostrado en otros estudios, el contenido fenólico y la actividad de la fenolsulfatasa incrementan en C. tamariscifolia cuando es incubada bajo altos niveles de PAR. Craigie y McLachlan (1964) analizaron el efecto de temperatura, $\mathrm{pH}$, salinidad y luz en la coloración del agua por puntas cortadas de Fucus vesiculosus y encontraron que esta especie excretó aproximadamente $0.25 \%$ de su 
exposed to stress conditions such as summer solar radiation. As also shown in other studies, phenolic content and phenolsulphatase activity increase in C. tamariscifolia when incubated under high PAR levels. Craigie and McLachlan (1964) observed the effect of temperature, $\mathrm{pH}$, salinity, and light on the coloration of seawater by the excised tips of Fucus vesiculosus. Their data indicate that $F$. vesiculosus excreted approximately $0.25 \%$ of its dry weight as flavonols or catechin-type tannins after $10 \mathrm{~h}$ at $20^{\circ} \mathrm{C}$. Similarly, F. vesiculosus can excrete at least $0.05 \%$ of its dry weight as phenolic material over a 24-h period at $6-7^{\circ} \mathrm{C}$ (Sieburth and Jensen 1969). These authors also reported an increase in phenolic material as a result of increasing salinities in the seawater. Our results show that the excretion of phenolic compounds increases in tissue exposed to high PAR levels. These results suggest that excretion of phenolic compounds might function as a protective mechanism serving as a radiation filter in the immediate surroundings of the $C$. tamariscifolia thalli.

Phenolic compounds and mycosporine-like amino acids function as a protective mechanism against high light levels in a number of seaweeds (Korbee et al. 2006). In C. tamariscifolia, the apical portion of the thallus is exposed to higher levels of irradiance while the basal section is fixed to the substratum and hidden from high PAR levels (AbdalaDíaz 2001). Under these circumstances the apical section of the thallus would need greater levels of protection against photodamage. The higher levels of phenolic compounds in the apical section are consistent with the greater irradiance exposure. In addition, the correlation between integrated irradiance dosage and phenol excretion indicates that there is a rapid response to increasing light levels.

The content of phenols in the thallus is a balance between synthesis and excretion. Two different internal phlorotannin fractions have been described: a soluble fraction located in the physodes of cytoplasm and an insoluble cell wall-bound fraction (Koivikko et al. 2005, Gómez and Huovinen 2010). The proportion of excretion and soluble/insoluble phlorotannins can be affected by seasonal acclimation and intrinsic morpho-functional processes (Gómez and Huovinen 2010). Thus, in Lessonia nigrescens growing in summertime, when the algae are naturally exposed to high UV irradiances, soluble phlorotannins are induced and a high rate of excretion is observed, while their transition to insoluble phlorotannins could be related to growth requirements, as active blade elongation occurs in this season (Gómez and Huovinen 2010).

The positive correlation between phenol compound content in the tissues and antioxidant activity in C. tamariscifolia suggests that the active compounds found in the extracts from thallus parts are mainly phenolic substances. This is in agreement with other studies that show that the antioxidant activity of the extracts measured by the DPPH assay is closely related to the phenolic content in brown algae (Jiménez-Escring et al. 2001). Similarly, a relation between coumarins and antioxidant activity has been observed in the green alga D. vermicularis (Pérez-Rodríguez et al. 2001). peso seco como flavonoides después de $10 \mathrm{~h} \mathrm{a} 20^{\circ} \mathrm{C}$. Asimismo, F. vesiculosus puede excretar al menos $0.05 \%$ de su peso seco como material fenólico en un periodo de $24 \mathrm{~h}$ a $6-7^{\circ} \mathrm{C}$ (Sieburth y Jensen 1969). Estos autores también observaron un aumento de material fenólico al incrementar la salinidad del agua. Nuestros resultados muestran que la excreción de compuestos fenólicos aumenta en tejido expuesto a niveles altos de PAR. Estos resultados sugieren que la excreción de compuestos fenólicos puede funcionar como un mecanismo de protección proporcionando un filtro de radiación en las inmediaciones de los talos de C. tamariscifolia.

Los compuestos fenólicos y los aminoácidos tipo micosporina funcionan como un mecanismo de defensa contra altos niveles de luz en varias algas marinas (Korbee et al. 2006). En C. tamariscifolia, la porción apical del talo queda expuesta a mayores niveles de radiación, mientras que la sección basal está fija al sustrato y protegida de altos niveles de PAR (Abdala-Díaz 2001). En estas circunstancias la sección apical del talo necesitaría una mayor protección contra el fotodaño. Los mayores niveles de compuestos fenólicos en la sección apical son consistentes con una mayor exposición a radiación. Además, la correlación entre la dosis de radiación integrada y la excreción de fenoles indica que hay una respuesta rápida a un incremento en los niveles de luz.

El contenido de fenoles en el talo es un balance entre la síntesis y la excreción. Se han descrito dos diferentes fracciones internas de florotaninos: una fracción soluble en los fisoides del citoplasma y una fracción insoluble unida a la pared celular (Koivikko et al. 2005, Gómez y Huovinen 2010). La proporción de excreción y florotaninos solubles e insolubles puede ser afectada por procesos morfofuncionales intrínsecos y el proceso de aclimatación estacional (Gómez y Huovinen 2010). En Lessonia nigrescens, durante el verano cuando las algas están expuestas a altos niveles de radiación UV, se inducen los florotaninos solubles y se observa una alta tasa de excreción, mientras que su transición a florotaninos insolubles puede estar relacionada con requerimientos de crecimiento ya que el alargamiento de las hojas sucede durante esta temporada (Gómez y Huovinen 2010).

La correlación positiva entre el contenido de compuestos fenólicos en los tejidos y la actividad antioxidante de C. tamariscifolia sugiere que los compuestos activos en los extractos de las secciones del talo son principalmente sustancias fenólicas. Esto coincide con otros estudios que muestran que la actividad antioxidante de los extractos medidos mediante el método de DPPH se relaciona estrechamente con el contenido fenólico de algas pardas (Jiménez-Escring et al. 2001). También se ha observado una relación entre las coumarinas y la actividad antioxidante en el alga verde D. vermicularis (Pérez-Rodríguez et al. 2001). 


\section{ACKNOWLEDGMENTS}

This study was financed by the Spanish Ministry of Science and Innovation (project CGL08-05407-C03-01). RTAD thanks the Spanish Agency of International Development Cooperation (AECID). The authors are grateful for the use of the facilities of the Delegación Provincial (Consejería de Medio Ambiente, Junta de Andalucía) in the Cabo de Gata-Níjar Natural Park.

\section{REFERENCES}

Abdala-Díaz RT. 2001. Fotocontrol de la acumulación de compuestos fenólicos en algas pardas. PhD dissertation, Universidad de Málaga, 325 pp.

Abdala-Díaz R, Cabello-Pasini A, Pérez-Rodríguez E, CondeAlvarez R, Figueroa FL. 2006. Daily and seasonal variations of optimum quantum yield and phenolic compounds in Cystoceira tamariscifolia (Phaeophyta). Mar. Biol. 148: 459-465.

Bellassoued K, Hamza A, Abdelmouleh A, van Pelt CJ, Elfeki A. 2012. Antioxidant response of a common herbivorous fish species (Sarpa salpa): Seasonal variation. Cienc. Mar. 38: 57-71.

Brand-Williams W, Cuvelier M, Berset C. 1995. Use of a free radical method to evaluate antioxidant activity. Lebensm. Wiss. Technol. 28: 25-30.

Connan S, Goulard F, Stiger V, Deslandes E, Ar Gall E. 2004. Interspecific and temporal variation in phlorotannin levels in an assemblage of brown algae. Bot. Mar. 47: 410-416.

Connan S, Deslandes E, Ar Gall E. 2007. Influence of day-night and tidal cycles on phenol content and antioxidant capacity in three temperate intertidal brown seaweeds. J. Exp. Mar. Biol. Ecol. 349: 359-369.

Craigie JS, McLachlan J. 1964. Excretion of coloured ultravioletabsorbing substances by marine algae. Can. J. Bot. 42: 23-33.

Farooqui AA, Samiullah S, Afridi MMRK. 1977. Arylsulphatase activity of corn (Zea mays L.) seedling roots. Planta 133: $157-160$

Folin O, Ciocalteu V. 1927. On tyrosine and tryptophane determinations in protein. J. Biol. Chem. 12: 239-243.

Geiselman JL. 1980. Ecology of chemical defenses of algae against the herbivorous snail, Littorina littorea, in the New England rock intertidal community. Dissertation, Massachusetts Institute of Technology.

Gómez I, Huovinen P. 2010. Induction of phlorotannins during UV exposure mitigates inhibition of photosynthesis and DNA damage in the kelp Lessonia nigrescens. Photochem. Photobiol. 86: 1056-1063.

Goodwin TW, Mercer EI. 1988. Introduction to Plant Biochemistry. Pergamon Press, New York, 677 pp.

Hader DP, Figueroa FL. 1997. Photoecophysiology of marine macroalgae. Photochem. Photobiol. 66: 1-14.

Hader DP, Lebert M, Flores-Moya A, Jimenez C, Mercado J, Salles S, Aguilera J, Figueroa FL. 1997. Effects of solar radiation on the photosynthetic activity of the red alga Corallina elongata Ellis et Soland. J. Photochem. Photobiol. 37: 196-202.

Jiménez-Escring A, Jiménez-Jiménez I, Pulido R, Saura-Calixto F. 2001. Antioxidant activity of fresh and processed edible seaweeds. J. Sci. Food Agric. 81: 530-534.

Knöss W, Glombitza KW. 1993. A phenolsulphatase from the marine brown alga Cystoseira tamariscifolia. Phytochemistry 32: 1119-1123.

\section{Agradecimientos}

Este trabajo fue financiado por el Ministerio de Ciencia e Innovación de España (proyecto CGL08-05407-C03-01). El primer autor agradece la Agencia Española de Cooperación Internacional para el Desarrollo. Los autores agradecen el uso de las facilidades de la Delegación Provincial (Consejería de Medio Ambiente, Junta de Andalucía) en el Parque Natural Cabo de Gata-Níjar.

Traducido al español por Christine Harris.

Koivikko R, Loponen J, Honkanen T, Jormalainen V. 2005. Contents of soluble, cell-wall-bound and exuded phlorotannins in the brown alga Fucus vesiculosus, with implications on their ecological aspects. J. Chem. Ecol. 31: 195-212.

Korbee N, Figueroa F, Aguilera J. 2006. Effect of light quality on the accumulation of photosynthetic pigments, proteins and mycosporine-like aminoacids in the red alga Porphyra leucosticta (Bangiales, Rhodophyta). Mar. Biol. 80: 71-78.

Lohrmann N, Logan B, Johnson A. 2004. Seasonal acclimatization of antioxidants and photosynthesis in Chondrus crispus and Mastocarpus stellatus, two co-occurring red algae with differing stress tolerances. Biol. Bull. 207: 225-232.

Pavia H, Toth GB. 2000. Inducible chemical resistance to herbivory in the brown seaweed Ascophyllum nodosum. Ecology 81: 3212-3225.

Pavia H, Cervin G, Lindgren A, Aberg P. 1997. Effects of UV-B radiation and simulated herbivory on phlorotannins in the brown alga Ascophyllum nodosum. Mar. Ecol. Prog. Ser. 157: 139-146.

Pedersen A. 1984. Studies on phenol content and heavy metal uptake in fucoids. Proc. Int. Seaweed Symp. 11: 498-504.

Pérez-Rodríguez E, Aguilera J, Gómez I, Figueroa FL. 2001. Excretion of coumarins by the Mediterranean green alga Dasycladus vermicularis in response to enviromental stress. Mar. Biol. 139: 633-639.

Ragan MA, Glombitza KW. 1986. Phlorotannins, brown algal polyphenols. Prog. Phycol. Res. 4: 129-241.

Rao CKH, Untawale AG. 1991. Polyphenols content of Indian seaweeds. Mahasagar 24: 99-102.

Rodríguez-Troncoso AP, Carpizo-Ituarte E, Cupul-Magaña A. 2013. Oxidative damage associated with thermal stress in Pocillopora verrucosa from the Mexican Pacific. Cienc. Mar. 39: 113-118. http://dx.doi.org/10.7773/cm.v39i1.2168

Schoenwaelder M. 2002. The occurrence and cellular significance of physodes in brown algae. Phycologia 41: 125-139. http://dx.doi.org/10.2216/i0031-8884-41-2-125.1

Sieburth J, Jensen JR. 1969. Studies on algal substances in the sea. II. The formation of Gelbstoff (humic material) by exudates of Phaeophyta. J. Exp. Mar. Biol. Ecol. 3: 275-289.

Sokal RR, Rohlf FJ. 1995. Biometry. WH Freeman, New York, $887 \mathrm{pp}$.

Swanson AK, Druehl L. 2002. Induction, exudation and the UV protective role of kelp phlorotannins. Aquat. Bot. 73: 241-253.

Targett NM, Boettcher AA, Targett TE, Vrolijk NH. 1995. Tropical marine herbivore assimilation of phenolic-rich plants. Oecologia 103: 170-179. 
Vreeland V, Waite J, Epstein L. 1998. Polyphenols and oxidases in substratum adhesion by marine algae and mussels. J. Phycol. 34: $1-8$.

Waterman PG, Mole S. 1994. Analysis of Phenolic Plant Metabolites. Blackwell Scientific, Oxford, 248 pp.

Yates J, Peckol P. 1993. Effects of nutrient availability and herbivory on polyphenolics in the seaweed Fucus vesiculosus. Ecology 74: 1757-1766.
Zubia M, Fabre MS, Kerjean V, Lann KL, Stiger-Pouvreau V, Fauchon M, Deslandes E. 2009. Antioxidant and antitumoural activities of some Phaeophyta from Brittany coasts. Food Chem. 116: 693-701.

Received October 2013, accepted January 2014. 